\title{
KARAKTERISTIK SEDIAAN GARAM Ulva lactuca DARI PERAIRAN SEKOTONG NUSA TENGGARA BARAT BAGI PASIEN HIPERTENSI
}

\author{
Nurjanah $^{*}$, Asadatun Abdullah, Chairun Nufus \\ Departemen Teknologi Hasil Perairan, Fakultas Perikanan dan Ilmu Kelautan, \\ Institut Petanian Bogor Institut Pertanian Bogor, Kampus IPB Darmaga, Jalan Agatis, Bogor 16680 Jawa \\ Barat, Telepon (0251) 8622909-8622906, Faks. (0251) 8622915 \\ *Korespodensi:inun_thp10@yahoo.com \\ Diterima: 16 Februari 2018/ Disetujui: 6 April 2018
}

Cara sitasi: Nurjanah, Abdullah A, Nufus C. 2018 Karakteristik sediaan garam Ulva lactuca dari perairan sekotong Nusa Tenggara Barat bagi pasien hipertensi. Jurnal Pengolahan Hasil Perikanan Indonesia. 21(1): $109-117$.

\begin{abstract}
Abstrak
Rumput laut hijaumenghasilkan berbagai senyawa bioaktif yang dapat dimanfaatkan dalam bidang industri farmaseutika, biomedika dan nutraseutika. Penelitian ini bertujuan untuk menentukan karakteristik dan aktivitas antioksidan garam rumput laut hijau sebagai sediaan garam bagi pasien hipertensi. Rancangan percobaan yang digunakan adalah rancangan acak lengkap (RAL) dengan perlakuan perbedaan suhu (40,55 dan $70^{\circ} \mathrm{C}$ ) dan waktu (10 dan 30 menit) pembuatan garam dengan ulangan sebanyak 3 kali. Analisis yang dilakukan pada penelitian ini adalah:aktivitas antioksidan dengan metode FRAP dan CUPRAC, kandungan mineral, kadar $\mathrm{NaCl}$, rendemen dan residu logam berat. Hasil penelitian menunjukkan interaksi antara waktu dan suhu tidak memberikan pengaruh nyata pada taraf $(\mathrm{p}<0,05)$ terhadap rendemen garam rumput laut, namun berpengaruh nyata pada rasio $\mathrm{Na}: \mathrm{K}$ dan kadar $\mathrm{NaCl}$. Residu logam berat pada bahan baku dapat diturunkan lebih dari 95\%. Aktivitas antioksidan garam rumput laut dengan metode FRAP 122,50130,69 $\mu \mathrm{mol}$ troloks/g dan CUPRAC 20,12-26,09 $\mu \mathrm{mol}$ troloks/g. Garam rumput laut terbaik sebagai sediaan garam antihipertensi adalah perlakuan suhu $40^{\circ} \mathrm{C}$ waktu 10 menit dengan rasio Na:K 2,95.
\end{abstract}

Kata kunci: antioksidan, hipertensi, logam berat, mineral, rumput laut hijau

\section{Characteristics of Ulva lactuca from Sekotong West Nusa Tenggara as seaweed salt preparation for hypertensive patients}

\begin{abstract}
Green seaweed producesvariety of bioactive compounds that can be utilized in the field of industrial pharmaceuticals, biomedicine and nutraceuticals. This study was aimed to determine the characteristics and antioxidant activity of green seaweed salt specifically for hypertensive patient's salt. The experimental design was complete randomized design (RAL) with temperature difference treatment $\left(40,55\right.$ and $\left.70^{\circ} \mathrm{C}\right)$ and salt making time (10 and $30 \mathrm{~min}$ ) with 3 times replication. The study consisted of analysis of antioxidant activity with FRAP and CUPRAC method, mineral content, $\mathrm{NaCl}$ content, yield and heavy metal residue. The results showed that the interaction between time and temperature did not give a significant effect on the $(\mathrm{p}<0.05)$ level on the salt content of seaweed, however, the effect was significantly on $\mathrm{Na}: \mathrm{K}$ and $\mathrm{NaCl}$. Heavy metal residues on raw materials can be lowered by more than $95 \%$. Antioxidant activity of seaweed salt by FRAP method 122,50-130,69 $\mu \mathrm{mol}$ trolox/g and CUPRAC 20,12-26,09 $\mu \mathrm{mol}$ trolox/g. The best treatment for an antihypertensive salt productionis a treatment of $40^{\circ} \mathrm{C} 10 \mathrm{~min}$ with Na: K ratio of 2.95 .
\end{abstract}

Keywords: green seaweed, heavy metals, hypertension, minerals

\section{PENDAHULUAN}

Rumput laut telah digunakan sebagai makanan di banyak negara Asia termasuk Indonesia, Malaysia, Filipina, Singapura, Vietnam dan Taiwan (Nguyen et al. 2011; Nagappan dan Vairappan 2014) serta di sebagian negara Pasifik (Paul et al. 2013; Morris et al. 2014). Rumput laut yang menjadi konsumsi rutin masyarakat contohnya dari kelas Cholorophyta (Caulerpa recemosa, Caulerpa lentillifera, Ulva lactuca) dan Rhodophyta (Eucheuma cottonii, Eucheuma 
spinosum, Gracilaria gigasdan Gelidium).

Pemerintah menjadikan rumput laut sebagai salah satu dari empat komoditiindustrialisasiutama perikananselain udang, kepiting dan tuna.Volume dan nilai ekspor rumput laut menduduki urutan kedua komoditas hasil perikanan budidaya setelah udang. Produksi rumput laut pada tahun 2011 yaitu 5,1 juta ton dan mengalami peningkatan pada tahun 2013 mencapai 9,31 juta ton, pada tahun 2016 menjadi 11,69 juta ton, namun pada tahun 2017 mengalami penurunan menjadi 8,2 juta ton (KKP 2017).

Nusa Tenggara Barat sebagai provinsi pemasok rumput laut merah tertinggi setelah Sulawesi dengan total produksi $28,1 \%$ dari total produksi rumput laut nasional dan terus mengalami peningkatan pada setiap tahunnya (KKP 2014; 2017). Rumput laut merah telah banyak digunakan baik pada industri pangan maupun non pangan.Pemanfatan rumput laut merah pada industri pangan dalam bentuk pangan olahan berupa manisan rumput laut, dodol rumput laut, kopi rumput larut serta olahan lainnya.

Rumput laut hijau mempunyai kelimpahan yang sangat tinggi, terutama jenis Ulva sp. namun pemanfaatan Ulva sp. masih terbatas sebagai pakan bagi abalon. Pangan olahan dari rumput laut hijau saat ini masih terbatas berupa produk nori, peyek Ulva dan kripik Ulva. Rumput laut hijaumenghasilkan berbagai senyawa bioaktif (Nurjanah 2016; Perez et al. 2016, Nufus et al. 2017). Potensi senyawa bioaktif rumput laut hijau telah dikaji dalam beberapa penelitian di antaranya adalah rumput laut hijau sebagai antibakteri (Devi et al. 2009; Osman et al. 2013, Basir 2017) dan antioksidan (Novoa et al. 2011).

Antioksidan dapat meningkatkan kesehatan danberperan dalam mencegah munculnya penyakit kronis salah satunya dengan cara mencegah kerusakan sel (Brown et al. 2014). Potensi antioksidan yang dimiliki rumput laut memungkinkan untuk dimanfaatkan dalam berbagai bidang, terutama di bidang industri farmaseutika, biomedika dan nutraseutika. Rumput laut sebagai sumber antioksidan sudah diteliti di antaranya rumput laut sebagai bahan baku kosmetik (Nurjanah et al. 2006; Luthfiyana et al. 2017; Maharany et al. 2017; Yanuarti et al. 2017; Dolorosa et al. 2017). Rumput laut sebagai sediaan garam rumput lautbagipasien hipertensi(Diachntyetal.2017; Nufus et al. 2017) dan sumber nutraseutika dari ekstrak Sargasum aquifolium (Firdaus 2013).

Hipertensi merupakan penyakit yang paling banyak diderita pasien dengan jumlah kasus 4.420 tahun 2014, 95.087 tahun 2015 dan mengalami peningkatan pada tahun 2016 menjadi 739.820 kasusdengan kategoriberisiko rendah hingga tinggi (BPJS 2014, 2015, 2016). Konsumsi garam berlebih dipandang sebagai faktor risiko tinggi bagi penderita hipertensi. Produk garam rendah natrium $(\mathrm{NaCl}<95 \%)$ yang diklaimdapat membantu menjaga tekanan darah pasien hipertensi agar tetap dalam keadaan normal. Pembuatan garam dari rumput laut merupakan salah satu cara memanfaatkan bahan alami yang memiliki aktivitas antioksidan. Informasi mengenai karakterisasi dan cara pembuatan garam rumput laut hijau sebagai sediaan garam bagi pasien hipertensi belum dilaporkan, sehingga penelitian inidilakukan untuk menentukan waktu dan suhu terbaik dalam pembuatam garam rumput laut serta karakteristik dan aktivitas antioksidangaram rumput laut Ulva lactuca sebagai sediaan garam rumput laut bagi pasien hipertensi.

\section{BAHAN DAN METODE Bahan dan Alat}

Bahan yang digunakan pada penelitian ini antara lain rumput laut hijau U. lactuca yang diperoleh dari perairan Sekotong, Nusa Tenggara Barat, akuades, $\mathrm{FeCl}_{3}$ (Merck), etanol PA 99,9\% (Merck), asam askorbat (Merck), TPTZ (2,4,6- Tris (2-pyridyl)-s-triazine) (Sigma-Aldrich), Neocuproine (SigmaAldrich), serbuk Mg (Merck), amil alkohol (Merck), folin-ciocalteu (Merck), $\mathrm{Na}_{2} \mathrm{CO}_{3}$ (Merck), asam galat (Merck), asam askorbat (Merck), trolox (Merck), $\mathrm{CuCl}_{2} .2 \mathrm{H}_{2} \mathrm{O}$ (Merck), amonium asetat (Merck), $\mathrm{CH}_{3} \mathrm{COOH}$ (Merck), $\mathrm{CH}_{3} \mathrm{COONa}$ (Merck), $\mathrm{K}_{2} \mathrm{CrO}_{4}$ (Merck), $\mathrm{FeSO}_{4} \cdot 7 \mathrm{H}_{2} \mathrm{O}$ (Merck).

Alat yang digunakan terdiri dari water bath (SWBR17), vortex (VM-300), alat 
gelas (Pyrex), $\mathrm{pH}$ meter, mikro pipet (Gilson ${ }^{\circledR}$ ), AAS (Atomic Absorbtion Spectrofotometer) (Shimatzu AA-700), spectro UV-Vis RSS pectrofotometer (UV-2500), oven (Memmert, Jerman), timbangan analitik tipe 210-LC (Adam, Amerika Serikat).

\section{Metode Penelitian}

Penelitian ini dilaksanakan dalam dua tahap. Tahap pertama meliputi pengambilan, preparasi, identifikasidan penentuan residu logam berat $(\mathrm{Hg}, \mathrm{Pb}$ dan $\mathrm{Cu})$ bahan baku rumput laut hijau.Tahap kedua pemilihan waktu dan suhu yang paling optimal dalam pembuatan garam rumput laut. Tahap 3 karakterisisi garam yang dihasilkan meliputi analisis rendemen, aktivitas antioksidan dengan metode FRAP, Cupric Reducing Antioxidant Capacity (CUPRAC), kadar $\mathrm{Na}$ dan $\mathrm{K}$, kadar $\mathrm{NaCl}$ dan residu logam berat.

\section{Pengambilan dan preparasi bahan baku}

Rumput laut U. lactuca diambil pada bulan September2016. Sampel rumput laut diidentifikasi spesiesnyadiLembaga Ilmu Pengetahuan Indonesia (LIPI). Rumput laut dibersihkan dan disortirdari pasirdanbenda asing serta pencucian menggunakan air laut, di tiriskan kemudiandijemur dengan cara kering angin sampai kering (3-5 hari). Rumput laut kering dipotong-potong dan dihancurkan menggunakan blender hingga halus dan dilakukan pengayakan menggunakan saringan dengan ukuran 30 mesh.

\section{Pembuatan Garam Rumput Laut}

Pembuatan garam rumput laut mengacu pada Magnusson et al. (2016). Proses pembuatan garam rumput laut dimulai dengan penghalusan rumput laut dengan blender kemudian diayak.Proses pembuatan garam rumput laut dengan mencampurkan rumput laut dan akuades (1:10) dan dipanaskan menggunakan waterbath pada suhu $\left(40,55\right.$ dan $\left.70^{\circ} \mathrm{C}\right)$ dengan waktu $(10$ dan 30 menit) dan dilakukan pengadukan. Hasil campuran rumput laut dan akuades yang telah dipanaskan kemudian disaring menggunakan kain mesh size500 dan kertas saring, selanjutnya dilakukan pengeringan menggunakan oven pada suhu $60^{\circ} \mathrm{C}$ selama 24 jam.

\section{Pengukuran Rendemen}

Rendemen merupakan persentase dari perbandingan bobot akhir terhadap bobot awal rumput laut sebelum mengalami perlakuan, perhitungan rendemen mengacu pada (AOAC 2005).

\section{Uji aktivitas antioksidan dengan metode FRAP}

Uji ktivitas antioksidan dengan metode FRAP berdasarkan Benzie dan Strain (1996) yang dimodifikasi. Pereaksi FRAP berupa buffer asetat $300 \mathrm{mM} \mathrm{pH} \mathrm{3,6;} 10 \mathrm{mM}$ TPTZ (2,4,6-tripyridyl-striazine) dalam $40 \mathrm{mM}$ $\mathrm{HCl}$; dan $20 \mathrm{mM} \mathrm{FeCl}_{3} \cdot 6 \mathrm{H}_{2} \mathrm{O}$ dengan nisbah 10:1:1. Pengukuran absorbansi menggunakan 0,025 mL sampel, $0,6 \mathrm{~mL}$ akuades dan $3 \mathrm{~mL}$ reagen FRAP. Campuran sampel dan reagen FRAP kemudian dicampur menggunakan vortex, kemudian diinkubasi menggunakan waterbath suhu $37^{\circ} \mathrm{C}$ selama 30 menit. Pengukuran absorbansi dilakukan pada panjang gelombang $593 \mathrm{~nm}$. Nilai absorbansi dihitung dalam $\mathrm{Fe}^{+2}$ ekuivalen $\left(\mathrm{Fe}^{+2} \mathrm{mM}\right)$ menggunakan kurva standar $\mathrm{FeSO}_{4} \cdot 7 \mathrm{H}_{2} \mathrm{O}$ dengan konsentrasi $(20,40,60,80,100,120$, $140 \mu \mathrm{M}$ ) mengacupada (Hamed et al. 2012) dan dengan kurva standar trolox (trolox/g) $(25,50,75,100,125 \mu \mathrm{M})$ mengacu pada (Widyastuti et al. 2010).

\section{Uji aktivitas antioksidan dengan metode CUPRAC}

Uji aktivitas antioksidan dengan metode CUPRAC mengacu pada Apak et al. (2007), sampel sebanyak 0,05 g ditambahkan dengan $5 \mathrm{~mL}$ etanol 99,9\%, divortex dan disaring (Maryam et al. 2016). Ekstrak sebanyak 0,4 mL dilarutkan dalam etanol ditambahkan $1 \mathrm{~mL}$ $\mathrm{CuCl}_{2} \cdot 2 \mathrm{H}_{2} \mathrm{O} 0,01 \mathrm{M} ; 1 \mathrm{~mL}$ neokuproin etanolik $0,0075 \mathrm{M} ; 1 \mathrm{~mL}$ bufer amonium asetat $\mathrm{pH} 7$ 1M; dan 0,7 mL akuades. Larutan didiamkan selama 30 menit dan diukur absorbansinya pada $450 \mathrm{~nm}$. Campuran larutan tanpa ekstrak digunakan sebagai blanko. Kurva kalibrasi dibuat menggunakkan larutan trolox dengan berbagai konsentrasi. Kapasitas antioksidan dinyatakan dalam $\mu \mathrm{mol}$ troloks/g. 


\section{Analisis kadar mineral dan residu logam berat pada garam yang dihasilkan}

Analisis kadar mineral dan residu logam dan berat mengacu pada AOAC (2005), diawali dengan proses pengabuan basah. Garam sebanyak $10 \mathrm{~g}$ dimasukkan ke dalam erlenmeyer dan ditambah $5 \mathrm{~mL} \mathrm{HNO}_{3}$, dipanaskan dengan hot plate dengan suhu $120^{\circ} \mathrm{C}$ selama empat jam, kemudian ditambah $0,4 \mathrm{~mL} \mathrm{H}_{2} \mathrm{SO}_{4}$ dan dipanaskankembali di atas hot plate dan ditambahkan 2-3 tetes larutan campuran $\mathrm{HCl}$ dan $\mathrm{HNO}_{3}$ dengan perbandingan 2:1. Pemanasan ke 2 dilakuakan hingga terjadi perubahan warna dari cokelat ke kuning tua dan berubah menjadi kuning muda.Sampel didinginkan, ditambah $2 \mathrm{~mL}$ akuades dan 0,6 $\mathrm{mL} \mathrm{HCl}$. Larutan hasil pengabuan basah ditera ke dalam labu takar $100 \mathrm{~mL}$ menggunakan air demineral.

Analisis kadar mineral garam rumput laut terdiri atas natrium $(\mathrm{Na})$, dan kalium $(\mathrm{K})$ dengan panjang gelombang: $\mathrm{Na} 589,6 \mathrm{~nm}, \mathrm{~K}$ : $766,5 \mathrm{~nm}$ danlimit deteksi: $\mathrm{Na} 0,10 \mathrm{mg} / \mathrm{kg}, \mathrm{K}$ $0,18 \mathrm{mg} / \mathrm{kg}$. Analisis residu logam berat terdiri dari timbal $(\mathrm{Pb})$, tembaga $(\mathrm{Cu})$ dan merkuri $(\mathrm{Hg})$ dengan panjang gelombang: $\mathrm{Pb}$ 283,3 $\mathrm{nm}, \mathrm{Cu} 228,8 \mathrm{~nm}$ dan $\mathrm{Hg}$ 253,6 nm dan limit deteksi: timbal $(\mathrm{Pb}) \quad 0,23 \mathrm{mg} / \mathrm{kg}$, tembaga (Cu) $1,2 \mathrm{mg} / \mathrm{kg}$ dan merkuri (Hg) 0,004 mg/ kg. Pengukuran menggunakan AAS (Atomic Absorbtion Spectrofotometer).

\section{Analisis kadar $\mathrm{NaCl}$}

Analisis $\mathrm{NaCl}$ dilakukan dengan pengabuan basah mengacu pada Day dan Underwood (1994), Garam ditimbang sebanyak $250 \mathrm{mg}$, dicuci dengan akuades sebanyak $10 \mathrm{~mL}$ dan dipindahkan ke dalam erlenmeyer $250 \mathrm{~mL}$, larutan potasium kromat $\left(\mathrm{K}_{2} \mathrm{CrO}_{4}\right) 5 \%$ ditambahkan sebanyak $3 \mathrm{~mL}$ dan dititrasi dengan larutan perak nitrit $\left(\mathrm{AgNO}_{3}\right)$ 0,1 M. Titik akhir titrasi tercapai apabila timbul warna oranye atau jingga yang pertama. Kadar $\mathrm{NaCl}$ dapat dihitung dengan rumus sebagai berikut:

$$
\operatorname{garam}(\mathrm{NaCl})(\%)=\frac{(\mathrm{T} \times \mathrm{M} \times 58,4)}{\mathrm{W}(\mathrm{mg})} \times 100 \%
$$

Keterangan : $\mathrm{T}=$ Volume Larutan standar

$$
\mathrm{AgNO}_{3} 0,1 \mathrm{M}
$$

$$
\begin{aligned}
M & =\text { Molaritas perak nitrit } \\
W & =\text { Berat sampel }
\end{aligned}
$$

\section{Analisis Data}

Rancangan percobaan yang digunakan adalah Rancangan Acak Lengkap (RAL) dengan dua faktor. Data yang diperoleh diuji normalitas dan homogenitasnya sebelum dilakukan analisis ANOVA. Analisis data dilakukan dengan Analysis of Variant (ANOVA) pada selang kepercayaan 95\% $(\alpha=0,05)$. Perlakuan yang berpengaruh terhadaprespon, selanjutnya diuji lanjut Duncan.

\section{HASIL DAN PEMBAHASAN Karakteristik Bahan Baku}

Hasil identifikasi melalui pengamatan morfologi menunjukkan bahwa rumput laut yang digunakan dalam penelitian ini merupakan spesies U. lactuca, termasuk filum Chlorophytadan suku Ulvaceae. U. lactuca atau yang biasa dikenal dengan nama selada laut terdapat melimpah di wilayah pesisir dan laut Indonesia. Sebaran pertumbuhan $U$. lactuca di Indonesia meliputi daerah Sulawesi, Lombok, Jawa Barat, Lampung, Sulu, Sumba, Banda dan Solor, hidup di area intertidal dan subintertidal hingga kedalaman $10 \mathrm{~m}$ serta dapat menutupi substrat $85 \%$ $100 \%$, habitat Ulva yaitu melekat pada substrat dengan bantuan holdfast. Ulva banyak dijumpai di pantai berdasar batu karang mati terutama pada rataan terumbu karang (Giannoti dan Mc.Glathery 2001; Mahmud et al. 2014).

\section{Rendemen dan Mineral Garam Rumput Laut}

Hasil analisis rendemen dan mineral garam rumput laut disajikan pada Tabel 1

Hasil analisis sidik ragam menunjukkan interaksi antara waktu dan suhu tidak memberikan pengaruh nyata $(\mathrm{p}<0,05)$ terhadap rendemen garam rumput laut. Rendemen garam rumput laut berkisar 24,47-27,13\%. Perlakuan waktu dan suhu tidak mempengaruhi rendemen karena jumlah tepung rumput laut serta ukuran dari tepung rumput laut yang dipergunakan dalam pembuatan garam seragam sehingga garam yang dihasilkan memiliki rendemen yang 
Tabel 1Rendemen dan mineral garam rumput laut (Table 1 Yield and mineral seaweed salt)

\begin{tabular}{ccccc}
\hline Temperature $\left({ }^{\circ} \mathrm{C}\right)$ & Time (minute) & Yield (\%) & $\mathrm{Na}: \mathrm{K}$ & $\mathrm{NaCl}(\%)$ \\
\hline \multirow{2}{*}{40} & 10 & $26.53 \pm 0.76^{\mathrm{a}}$ & $2.95^{\mathrm{c}}$ & $13.93 \pm 0.51^{\mathrm{a}}$ \\
& 30 & $25.93 \pm 1.86^{\mathrm{a}}$ & $3.36^{\mathrm{b}}$ & $13.83 \pm 0.02^{\mathrm{a}}$ \\
\hline \multirow{2}{*}{55} & 10 & $25.27 \pm 1.97^{\mathrm{a}}$ & $3.80^{\mathrm{a}}$ & $12.62 \pm 0.20^{\mathrm{b}}$ \\
& 30 & $24.47 \pm 1.70^{\mathrm{a}}$ & $3.88^{\mathrm{a}}$ & $14.15 \pm 0.02^{\mathrm{a}}$ \\
\hline \multirow{2}{*}{70} & 10 & $27.13 \pm 1.70^{\mathrm{a}}$ & $3.43^{\mathrm{b}}$ & $12.16 \pm 0.50^{\mathrm{b}}$ \\
& 30 & $26.40 \pm 1.71^{\mathrm{a}}$ & $3.07^{\mathrm{c}}$ & $12.18 \pm 0.73^{\mathrm{b}}$ \\
\hline
\end{tabular}

tidak jauh berbeda.

Hasil uji lanjut Duncan menunjukkan bahwa interaksi antara waktu $(10$ dan 30 menit) serta suhu $\left(40,55\right.$ dan $\left.70^{\circ} \mathrm{C}\right)$ memberikan pengaruh nyata pada taraf 0,05 $(\mathrm{p}<0,05)$ terhadap rasio Na:K. Rasio Na:K berkisar dari 2,95-3,88, rasio $\mathrm{Na}$ K $\mathrm{K}$ mengalami peningkatan pada garam rumput laut pada semua perlakuan dibandingkan dengan bahan baku, karena penggunaan akuades pada proses pembuatan garam dapat menurunkan kadar $\mathrm{Na}$ dan meningkatkan kadar $\mathrm{K}$. Proses pembuatan garam menggunakan oven menyebabkan terjadinya pemekatan sehingga kandungan mineral meningkat. Pada penelitian Magnuson et al. (2016), proses pencucian dapat menurunkan kadar abu dari rumput laut namun meningkatkan kandungan mineral yang lain.

Natrium dan kalium merupakan mineral makro yang erat hubungannya dalam berbagai jaringan tubuh, yaitu pasangan mineral yang bekerja sama dalam memelihara keseimbangan cairan elektrolit dan asam basa sehingga dua mineral tersebut berpengaruh terhadap regulasi tekanan darah. Hedayati et al. (2012) menyatakan bahwa peningkatan tekanan darah sistolik dan diastolik berhubungan dengan kenaikan rasio Na:K yang dihubungkan dengan asupan natrium yang tinggi dan kalium yang rendah, sehingga dibutuhkannya rasio $\mathrm{Na}: \mathrm{K}$ yang seimbang. Rasio Na:K yang dianjurkan maksimum 1:1. Rasio Na:K penting untuk mengontrol tekanan darah dan keluarnya cairan yang mengandung $\mathrm{K}$ secara berlebihan pada penderita hipertensi. Venughopal (2010) menyatakanbahwakaliumdapatmeningkatkan pertumbuhan sel dan membantu menjaga tekanan darah tetapnormal, natriumpada kadar normaldiperlukan untuk menjaga keseimbangan cairan osmotik dan asam basa.

Asupan natrium yang terdapat di dalam garam dapur secara berlebihan akan menimbulkan masalah ginjal. Ginjal yang berfungsi mengatur kebutuhan natrium tidak dapat membuang kelebihan natrium, akibatnya natrium menumpuk dalam darah. Natrium memiliki sifat menarik dan menahan air sehingga menyebabkan volume darah meningkat, jantung memompa lebih keras sehingga tekanan darah dalam pembuluh arteri meningkat yang kemudian menyebabkan hipertensi (Muaris 2009).

Natrium klorida $(\mathrm{NaCl})$ merupakan salah satupelengkap pangan dan sumberelektrolit bagi tubuh manusia. Hasil uji lanjut Duncan menunjukkan interaksi antara waktu (10 dan 30 menit) serta suhu $\left(40,55\right.$ dan $\left.70^{\circ} \mathrm{C}\right)$ memberikan pengaruh nyata pada taraf 0,05 $(\mathrm{p}<0,05)$ terhadap kadar $\mathrm{NaCl}$ yang dihasilkan. Hasil tersebut menunjukkan bahwa suhu dan waktu dapat mengoptimalkan terekstraknya mineral $\mathrm{NaCl}$ dari rumput laut.Kadar $\mathrm{NaCl}$ berkisar dari 12,16-14,15\%, dan tergolong rendah jika dibandingkan dengan garam konsumsi.Kadar standar $\mathrm{NaCl}$ minimum 94\% (BSN 2016), sedangkan kadar $\mathrm{NaCl}$ garam diet maksimum 60\% (PERMENPERIN 2014), sehingga kadar $\mathrm{NaCl}$ garam rumput laut pada penelitian ini sesuai dengan peraturan PENMENPERIN 2014 mengenai standar garam diet. 
Persyaratan garam menurut SNI selain dari kadar $\mathrm{NaCl}$ juga harus memenuhi standar logam berat maksimal yang ditetapkan. Residu logam berat dari garam terbaik pada perlakuan suhu $40^{\circ} \mathrm{C}$ dan waktu 10 menit (Tabel 2).

Penurunan residu logam berat yang signifikan pada garam rumput laut dibandingkan dengan bahan baku, karena logam berat masih terikat kuat pada ampas. Logam berat terikat kuat pada jaringan tanaman (Budiono 2003). Logam berat tidak terlarut selama proses perebusan menggunakan suhu 40,55 dan $7^{\circ} \mathrm{C}$, sehingga hasil filtrat yang selanjutnya dijadikan garam berkurang residu logam beratnya. Residu logam berat berkurang lebih dari $95 \%$ pada proses pembuatan garam. Slade (1988) melaporkan pengurangan residu logam berat $\mathrm{Cd}$ dan $\mathrm{Hg}$ hanya akan terjadi pada sampel yang dipanaskan dengan api secara langsung dan dengan jangka waktu yang lama.
Beberapa penelitian untuk mengurangi residu logam berat pada biota akuatik antara lain penggunaan NTA(Nitrilotriaceticacid), EDTA (Ethylen diamine tetra acetic acid), DDTA(3,6dioxa-octamethylene dinitrilo tetra acetic acid), DTPA(Diethylene triamine penta aceitic acid) dan DDC (Sodium diethyl dithiocarbamate), penggunaan larutan kitosan dan karboksimetil kitosan, penggunaan larutan asam cuka 5\% (Verma et al. 1981; Murtini et al. 2004; Murtini et al. 2008; Nurjanah et al. 1999).

\section{Aktivitas Antioksidan Garam Rumput Laut}

Hasil pengujian aktivitas antioksidan garam rumput laut disajikan pada Tabel 3.

Hasil uji lanjut Duncan menunjukkan interaksi antara waktu (10 dan 30 menit) serta suhu $\left(40,55\right.$ dan $\left.70^{\circ} \mathrm{C}\right)$ memberikan pengaruh nyata pada taraf $0,05 \quad(\mathrm{p}<0,05)$ terhadapaktivitas antioksidan garam rumput laut metode FRAP dan CUPRAC

Tabel 2 Residu logam berat rumput laut dan garam rumput laut

(Table 2 Residues heavy metals of seaweed and seaweed salt)

\begin{tabular}{cccc}
\hline Parameter & $\begin{array}{c}\text { U. lactuca }(\mathrm{mg} / \mathrm{kg}) \\
\text { (Nufus et al. 2018) }\end{array}$ & $\begin{array}{c}\text { Seaweed salt } \\
(\mathrm{mg} / \mathrm{kg})\end{array}$ & Standard $(\mathrm{mg} / \mathrm{kg})$ \\
\hline Timbal/Lead $(\mathrm{Pb})$ & 13.570 & $<0.040$ & max. $10^{\star *}$ \\
Merkuri/Mercury $(\mathrm{Hg})$ & 0.260 & $<0.002$ & max. $0.1^{\star *}$ \\
Cuprum/Copper $(\mathrm{Cu})$ & 8.320 & 1.949 & max. $10^{*}$ \\
\hline
\end{tabular}

Keterangan : ${ }^{\star}$ BSN 2000; ${ }^{* *}$ BSN 2010

Information : * BSN 2000; ** BSN 2010

Tabel 3 Aktivitas Antioksidan Garam Rumput laut (Table 3 Antioxidant activity of seaweed salt)

\begin{tabular}{ccccc}
\hline \multirow{2}{*}{ Temperature $\left({ }^{\circ} C\right)$} & Time $($ minute $)$ & FRAP & FRAP & CUPRAC \\
\cline { 2 - 5 } & & $(\mu \mathrm{mol} \mathrm{troloks} / \mathrm{g})$ & $\mu \mathrm{mol} \mathrm{Fe}^{2} / \mathrm{g}$ & $(\mu \mathrm{mol} \mathrm{troloks} / \mathrm{g})$ \\
\hline 40 & 10 & $122.50 \pm 1.67^{\mathrm{d}}$ & $92.50 \pm 0.35^{\mathrm{d}}$ & $22.86 \pm 0.071^{\mathrm{c}}$ \\
\hline & 30 & $130.69 \pm 0.35^{\mathrm{a}}$ & $118.88 \pm 0.18^{\mathrm{c}}$ & $23.54 \pm 1.231^{\mathrm{bc}}$ \\
\hline 55 & 10 & $129.36 \pm 0.07^{\mathrm{b}}$ & $120.00 \pm 0.35^{\mathrm{b}}$ & $26.09 \pm 0.148^{\mathrm{a}}$ \\
\hline 70 & 30 & $127.50 \pm 0.19^{\mathrm{c}}$ & $125.13, \pm 0.53^{\mathrm{a}}$ & $20.12 \pm 0.229^{\mathrm{d}}$ \\
\hline & 10 & $128.05 \pm 0.11^{\mathrm{c}}$ & $125.50 \pm 0.71^{\mathrm{a}}$ & $25.36 \pm 0.142^{\mathrm{a}}$ \\
\hline & 30 & $127.95 \pm 0.34^{\mathrm{c}}$ & $124.88 \pm 0.88^{\mathrm{a}}$ & $23.86 \pm 0.123^{\mathrm{b}}$ \\
\hline
\end{tabular}


yang dihasilkan.Perlakuan 10 menit $70^{\circ} \mathrm{C}$ cenderung menunjukan aktivitas antioksidan terbaik. Chew et al. (2011) menyatakan bahwa aktivitas antioksidan suatu bahan alami berhubungan erat dengan senyawa bioaktif yang dikandungnya, sehingga pemilihan metode ekstraksi yang digunakan sangat mempengaruhi nilai aktivitas antioksidan yang dihasilkan.

Pengujian aktivitas antioksidan menggunakan metode FRAP menunjukkan garam rumput laut memiliki kemampuan mereduksi ion ferri $\left(\mathrm{Fe}^{3+}\right.$ menjadi $\left.\mathrm{Fe}^{2+}\right)$, hal tersebut dapat menggambarkan bahwa garam rumput laut memiliki aktivitas antioksidan. Bahan dapat dikatakan sebagai antioksidan sangat kuat apabila memiliki nilai kapasitas antioksidan lebih dari $500 \mu \mathrm{mol} \mathrm{Fe} / \mathrm{g}$, kuat apabila nilainya $100-500 \mu \mathrm{mol} \mathrm{Fe} / \mathrm{g}$, medium

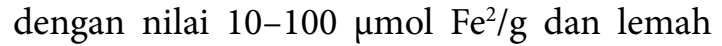
apabila memiliki nilai $<10 \mu \mathrm{mol} \mathrm{Fe}{ }^{2} / \mathrm{g}$ (Wong 2006), maka kemampuan garam rumput laut sebagai antioksidan dapat digolongkan kuat.

Aktivitas antioksidan dengan metode CUPRAC menunjukkan kemampuan garam rumput lautdalam mereduksi logam $\mathrm{Cu}$, hasil yang ditunjukkan sebanding dengan jumlah total tembaga yang direduksi oleh garam rumput laut mealalui tranfer elektron. Antioksidan akan mengalami oksidasi sedangkan tembaga akan direduksi. Aktivitas antioksidan metode CUPRAC dilihat dari kemampuannya dalam mereduksi kelat $\mathrm{Cu}^{2+} \mathrm{Nc}$ yang berwarna biru toska menjadi $\mathrm{Cu}^{+} \mathrm{Nc}$ yang berwarna kuning yaitu dengan cara menyumbangkan elektron yang dimiliki oleh antioksidan (Apak et al. 2007).

\section{KESIMPULAN}

Garam rumput laut perlakuan suhu $40^{\circ} \mathrm{C}$ selama 10 menit menghasilkan rasio $\mathrm{Na}: \mathrm{K}$ yang rendah serta kadar $\mathrm{NaCl}<60 \%$ sesuai dengan kriteria garam untuk pasien hipertensi. Garam rumput laut juga memiliki aktivitas antioksidan kuat sehingga berpotensi sebagai sumber antioksidan.

\section{DAFTAR PUSTAKA}

[AOAC]Association of Analytical Chemist Publisher. 2005. Official methods of analysis of the association of official analytical chemist. Arlington Virginia USA: The Association of Official Analytical Chemist, Inc. Mayland. USA.

Apak R, Kubilay G, Birsen D, Mustafa O, Saliha EC, Burcu,Berker IK, Dilek O. 2007. Comparative evaluation of various total antioxidant capacity assay applied to phenolic compounds with the CUPRAC assay. Molecules.12:1496-1547.

Basir A, Tarman K, Desniar. 2017. Aktivitas antibakteri dan antioksidan alga hijau Halimeda gracilis dari Kabupaten Kepulauan Seribu. Jurnal Penolahan Hasil Perikanan Indonesia.20(2): 211-218.

Benzie IFF, Strain JJ. 1996. The ferric reducing ability of plasma (FRAP) as a measurement ofantioxidant power: the FRAP assay. Analytical Biochemistry. 239: 70-76.

[BPJS]Badan Penyelenggara Jaminan Sosial. Jumlah peserta pengguna BPJS kesehatan tahun 2014, 2015, 2016. Available from URL: HIPERLINK http://bpjs-kesehatan. go.id di akses 4 Januari 2017 pukul 15: 24.

Brown ES, Allsopp PJ, Magee CI, Gill S, Nitecki CR, Strain EM. 2014. Seaweed and human health. British Jurnal of Nutrition.72: 205-216.

Budiono A. 2003. Pengaruh pencemaran air terhadap biota air.[Disertasi].Bogor. (ID): Institut Pertanian Bogor.

Chew KK, Ng SY, Thoo YY, Khoo MZ, Wan Aida WM, Ho CW. 2011. Effect ofethanol concentration, extraction time and extraction temperature on therecovery of phenolic compounds andantioxidant capacity of Centellaasiatica extracts. International Foof Research Jurnal. 18: 566-573.

Day RA, Underwood AL. 1989. Analisis Kimia Kuantitatif: Alih Bahasa. PudjaatmakaAH. Jakarta (ID):Erlangga.

Devi GK, Manivannan K, Thirumaran G, Anantharaman $\mathrm{P}$, Balasubaramanian T. 2009. Antibacterial properties of selected green seaweeds from Vedalai coastal waters Gulf of Mannar: marine biosphere reserve. Global Journal of Pharmacology.3(2):107-112.

Diachanty S, Nu rjanah, Abdullah A.2017. Aktivitas antioksidan berbagai jenis 
rumput laut coklat dari perairan Kepulauan Seribu.Jurnal Pengolahan Hasil Perikanan Indonesia. 20(2): 305318.

Dolorosa TM, Nurjanah, Purwaningsih S, Effionora A, Taufik H. 2017. Kandungan senyawa bioaktif bubur rumput laut Sargassum plagyophyllum dan Eucheuma cottonii sebagai bahan baku krim pencerah kulit.Jurnal Pengolahan Hasil Perikanan Indonesia. 20(3): 633-644.

Firdaus M. 2013.Indeks aktivitas antioksidan ekstrak rumput laut coklat Sargasum aquifolium.Jurnal Pengolahan Hasil Perikanan Indonesia.16(1): 42-47.

Giannoti AL, Mc.Glathery KJ. 2001. Consumption of Ulva lactuca chlorophyta by the omnivorous mud snail Ilyanassa obsoleta (Say). Journal of Aging and Physical Activity. 37: 209-215.

Hedayati SS, Minhajuddin AT, Ijaz A, Moe OW, Elsayed EF, Reilly RF, Huang CL. 2012. Association of urinary sodium/ potassium ratio with blood pressure: sex and racial differences. Clinical Jurnal of the American Society of Nephrology. 7(2): 315-322.

[KKP] Kementrian Kelautan dan Perikanan. 2017.https://news.kkp.go.id/index. php/kkp-sasar-rumput-laut-sebagaikomoditas-unggulan-budidaya/. [4 April 2018].

[KKP] Kementrian Kelautan dan Perikanan. 2014. Statistik Budidaya. http: www. kkp. go.id/. [3Maret 2018].

[KKP] Kementrian Kelautan dan Perikanan. 2017. Komoditas Rumput Laut Kian Strategis. http: www. kkp.go.id/. [3Maret 2018].

Luthfiana N, Nurjanah, Nurilmala M, Anwar E, Hidayat T. 2017.Karakterisasi sediaan krim tabir surya dari bubur rumput laut Eucheuma cottonii dan Sargassum sp. Jurnal Pengolahan Hasil Perikanan Indonesia.19(3): 183-195.

Mahmud I, Reza P, Nofa RA, Desi NR, 2014. Pemanfaatan potensi ganggang hijau (Ulva lactuca) sebagai antioksidan alami pada pencegahan infark miokard akut. [internet]. Diakses tanggal: 22 April 2017. Tersedia pada:http://www.artikel.dikti. go.id.

Nagappan T, Vairappan C. 2014. Nutritional and bioactive properties of threeedible species of green algae, genus Caulerpa (Caulerpaceae).Jurnal of Applied Phycology. 26:1019-1027.

Nguyen VT, UengJP, Ts a i GJ.2011. Proximatecomposition total phenolic content and antioxidant activity of seagrape (Caulerpa lentillifera).Jurnalof Food Science. 76:C950-C958.

Novoa AV. Andrade-Wartha ER. Linares AF, Genovese MI, González AEB, Vuorela P, Costa A, Mancini-Filho J. 2011. Antioxidant activity andpossible bioactive components in hydrophilic andlipophilic fractions from the seaweed Halimedaincrassata. Revista Brasileira Farmacognosia. 21(1):53-57.

Nufus C, Nurjanah, Abdullah A. 2017. Karakteristikrumput laut hijau dari perairan kepulauan seribu dan sekotong Nusa Tenggara Barat sebagai antioksidan. Jurnal Pengolahan Hasil Perikanan Indonesia. 20(3): 620-630.

Nurjanah, Hartanti, Nitibaskara RR. 1999. Analisa kandungan logam berat $\mathrm{Hg}$, $\mathrm{Cd}, \mathrm{Pb}, \mathrm{As}$ dan $\mathrm{Cu}$ dalam tubuh kerang konsumsi. Buletin Teknologi Hasil Perairan. 17(1): 19-23.

Nurjanah, Nurilmala M, Hidayat T, Sudirjo F. 2015.Characteristics of Seaweed as Raw Materials for Cosmetics.Aquatic Procedia. $7: 177-180$.

Magnusson M, Carl C, Mata L, Nys R, Paul NA. 2016. Seaweed salt from Ulva: a novel first step in a cascading biorefinery model. Biologi direct. 16(2016): 308-316.

Maharany P, Nurjanah, Ruddy S, Effionora A, Taufik H. 2017. Kandungan senyawa bioaktif rumput laut Padina australis dan Eucheuma cottonii sebagai bahan baku krim tabir surya. Jurnal Pengolahan Hasil Perikanan Indonesia. 20(1): 10-17.

Morris C, Bala S, South GR, Lako J, Lober M, Simos T. 2014. Supply chain andmarketing ofseagrapes, Caulerparacemosa (Forsskål) J. Agardh (Chlorophyta:Caulerpaceae) in Fiji, Samoa and Tonga.Jurnal of Applied Phycology. 26: 783-789.

Murtini JT, Januar HI, dan Sugiyono. 2004. 
Upayapengurangan cemaran logam berat pada dagingkerang hijau (Perna viridis) dengan larutan kitosan.Jurnal Penelitian PerikananIndonesia: 10(3): 7-10.

Murtini JT, Kurniawan AD, Dewi EK. 2008.Pengaruh waktu perendaman dan konsentrasikarboksimetil kitosan untuk menurunkan kandunganlogam berat $\mathrm{Hg}, \mathrm{Cd}$, dan $\mathrm{Pb}$ pada kerang hijau (PernaviridisLinn.). Jurnal Pascapanen dan BioteknologiKelautan dan Perikanan. 3(1): 37-44.

Osman MEH, Aboshady AM, Elshobary ME. 2013. Production and characterization of antimicrobial active substance from some macroalgae collected from AbuQir Bay Alexandria Egypt. Jurnal African Biotechnologi. 12(49): 6847-6858.

Paul NA, Neveux N, Magnusson M, de Nys R. 2013. Comparative productionand nutritional value of sea grapes the tropical green seaweeds Caulerpa lentilliferaand Caulerpa racemosa. Jurnal of Applied Phycology. 18: 1-12.

Perez MJ, Falqué E, Domínguez H. 2016. Antimicrobial action of compounds from marine seaweed-a review.Marine Drugs. 14 (52): 1-38.

[PERMENPERIN] Peraturan Mentri Perindustrian. 2014. Perubahan atas peraturan menteri perindustrian No 134/M-IND/PER/10/2009tentang peta panduan (Road Map) pengembangan klaster industry garam.

Racmawati R, Ma’ruf FW, Anggo DA. 2013. Pengaruh lama perebusan kerang darah Anadara granosa dengan arang aktif terhadap pengurangan kadar logam kadmium dan kadar logam timbal. Jurnal Penolahan Hasil Perikanan Indonesia. 2: 41-50.

Rahayu LH, Purnavita S. 2007.Optimasi pembuatan kitosan dari kitin limbah cangkang rajungan (Portunus pelagicus) untuk adsorben ion logam merkuri. Reaktor.11(1): 45-49.

Slade GP. 1988. The effect of temperature on the release of havy metals from $\mathrm{AgCdO}$ and $\mathrm{AgSnO}_{2}$ contacts. Institute of Electrical and Electronics Engineers Digital Library. 17-30.

Triani IGAL, Gunam IBW, Arnata IW. 2012. Identifikasi dan Pengurangan Kandungan $\mathrm{Pb}$ dan $\mathrm{Cd}$ pada kangkung. Penelitian Masalah Lingkungan di Indonesia. Research Gate.1: 203-212.

Venughopal JP. 2010. Omega-3 polyunsaturated acids and cardiovascular disease: notable ethnic differences or unfulfilled promise. Jurnal Thrombosis Haemostasis. 8:1095-2104.

Verma SR, Jain M, Dalela RC. 1981. In vivo removal of a few heavy metals in certain tissues of the fish Notopterus notopterus. Environmental Research. 26: 328-334.

Wong CC, Li HB, Cheng KW, Chen F. (2006). Asystematic survey of antioxidant activity of 30 Chinesemedicinal plants using the ferric reducing antioxidantpower assay. Food chemistry. 97: 705-711.

Yanuarti R, Nurjanah N, Anwar E, Hidayat T. 2017.Profil fenolik dan aktivitas antioksidan dari ekstrak rumput laut Turbinaria conoides dan Eucheuma cottonii.Jurnal Pengolahan Hasil Perikanan Indonesia. 20(2): 230-237. 